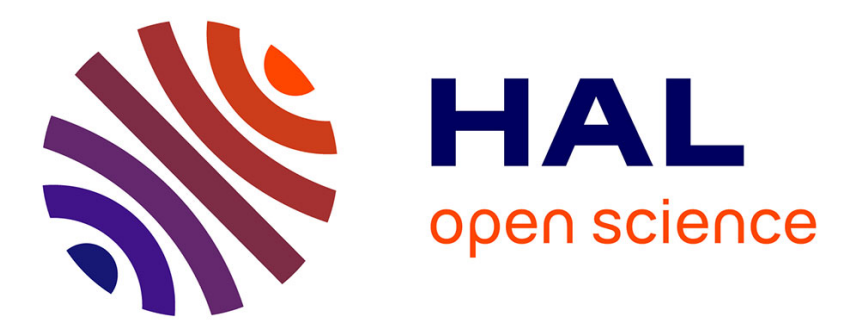

\title{
Protection against corrosion of magnesium alloys with both conversion layer and sol-gel coating
}

\author{
Noé Verner Murillo-Gutiérrez, Florence Ansart, Jean-Pierre Bonino, \\ Marie-Joëlle Menu, Marie Gressier
}

\section{- To cite this version:}

Noé Verner Murillo-Gutiérrez, Florence Ansart, Jean-Pierre Bonino, Marie-Joëlle Menu, Marie Gressier. Protection against corrosion of magnesium alloys with both conversion layer and sol-gel coating. Surface and Coatings Technology, 2013, vol. 232, pp. 606-615. 10.1016/j.surfcoat.2013.06.036 . hal-01169884

\section{HAL Id: hal-01169884 \\ https://hal.science/hal-01169884}

Submitted on 30 Jun 2015

HAL is a multi-disciplinary open access archive for the deposit and dissemination of scientific research documents, whether they are published or not. The documents may come from teaching and research institutions in France or abroad, or from public or private research centers.
L'archive ouverte pluridisciplinaire HAL, est destinée au dépôt et à la diffusion de documents scientifiques de niveau recherche, publiés ou non, émanant des établissements d'enseignement et de recherche français ou étrangers, des laboratoires publics ou privés. 


\section{OATAO \\ Open Archive Toulouse Archive Ouverte}

\section{Open Archive TOULOUSE Archive Ouverte (OATAO)}

OATAO is an open access repository that collects the work of Toulouse researchers and makes it freely available over the web where possible.

This is an author-deposited version published in : http://oatao.univ-toulouse.fr/ Eprints ID : 14036

To link to this article : DOI:10.1016/j.surfcoat.2013.06.036

URL : http://dx.doi.org/10.1016/j.surfcoat.2013.06.036

To cite this version : Murillo-Gutiérrez, Noé Verner and Ansart, Florence and Bonino, Jean-Pierre and Menu, Marie-Joëlle and Gressier, Marie Protection against corrosion of magnesium alloys with both conversion layer and sol-gel coating. (2013) Surface and Coatings Technology, vol. 232. pp. 606-615. ISSN 0257-8972

Any correspondance concerning this service should be sent to the repository administrator: staff-oatao@,listes-diff.inp-toulouse.fr 


\title{
Protection against corrosion of magnesium alloys with both conversion layer and sol-gel coating
}

\author{
N.V. Murillo-Gutiérrez *, F. Ansart, J-P. Bonino, M-J. Menu, M. Gressier \\ Université de Toulouse UPS-INP-CNRS, Institut Carnot CIRIMAT 118, Route de Narbonne, 31062 Toulouse CEDEX 09, France
}

\begin{abstract}
A B S T R A C T
The anticorrosion performances of a system consisting of a phosphate based conversion layer and a hybrid sol-gel coating have been evaluated for the magnesium alloy Elektron21. The lone sol-gel coating affords a significant protection of the magnesium substrate. However, the presence of an intermediate conversion layer is presumed to improve the corrosion resistance of the system. The surface morphology of the protection coatings was characterized by optical microscopy, scanning electron microscopy (SEM) and white-light source interferometry. The corrosion behavior of the systems was analyzed by electrochemical impedance spectroscopy (EIS). The impedance measurements show that the presence of the added conversion layer increases the resistance of the whole system during immersion in a $0.05 \mathrm{M} \mathrm{NaCl}$ solution, compared to the single sol-gel coating.
\end{abstract}

\section{Introduction}

In the recent past decades, the interest for weight-saving materials has increased considerably in the automotive as well as in the aeronautics field. Structural components and some mechanical parts are often made with materials presenting a favorable strength-toweight ratio, such as light metals and their alloys, which are widely used in industry. The constant challenge to improve the performances of vehicles led to search for multifunctional materials with improved properties. With a density equivalent to $2 / 3$ of that of aluminum, magnesium is a good candidate due to the fact that it is the lightest structural metal used in industry.

However, compared to steel and aluminum alloys used as structural materials, magnesium alloys have a very low corrosion resistance [1]. In order to improve its resistance, magnesium is often alloyed with other elements such as $\mathrm{Al}, \mathrm{Zn}, \mathrm{Zr}, \mathrm{Y}$, and rare-earths [2-4]. Among the family of rare-earth magnesium alloys, the Elektron21 alloy (El21) has been developed to enhance the anticorrosion and mechanical properties of magnesium [5]. Nevertheless, this alloy still presents poor corrosion resistance in most of aggressive environments, especially after exposure to moisture, or saline environment.

A way to prevent corrosion is to cover the base material by a protective coating. A number of surface treatments and coating techniques have been proposed and developed for magnesium alloys, including electrochemical plating, conversion coatings, anodizing, hybrid coatings, organic coatings and vapor-phase coatings [6,7]. Industrial processes such as anodizing have already been developed in the last

\footnotetext{
* Corresponding author. Tel.: +335615578 71 .

E-mail address: murillo@chimie.ups-tlse.fr (N.V. Murillo-Gutiérrez).
}

century, forming protective coatings with excellent protective properties for magnesium alloys. However, the production of these coatings which includes the utilization of hexavalent chromium ( $\mathrm{Cr}$ VI) compounds which have been classified as carcinogen, mutagenic and reprotoxic, will be strictly forbidden in the next years. That is why it is urgent to find effective and ecological technological alternatives.

For all of these reasons, the development of protective coatings that replaces the chromium-based treatments is a real key issue. In the literature, new protective coatings are reported and particularly relative to the production of conversion films for magnesium alloys. These films are composed of insoluble and stable compounds that protect the metallic substrate from corrosive species. These conversion treatments generally include the use of phosphates [8-13], phosphate-permanganate [14,15], fluorides [16-23] and rare earths [24-26]. However, the protection afforded by many of these coatings is limited, and generally they are used as a support base for additional coatings, like paints or/and other organic coatings [27].

In this context, hybrid inorganic/organic films have been widely studied for corrosion protection of steels, aluminum alloys, and other metallic substrates, with excellent results [28-33]. The sol-gel route proves to be an efficient method to produce these ceramic/polymeric coatings. This chemical process consists on the hydrolysis and condensation of metallic alkoxides in aqueous solution, transformed into a solid polymerized network. The chemical reactions involved in this route are described elsewhere [34]. Polymerization and condensation reactions of the sol-gel coatings can be accelerated by applying a heat treatment, and generally this is a crucial step to obtain a fully condensed film. The temperature and time of the heat treatment depend on the kind of precursors and solvents used to produce the coating, but economically it is more interesting to work at lower temperatures and 
shorter times. Many works report the production of sol-gel coatings with low-temperature heat treatments [33,35-42].

In this work, the anticorrosion properties of a combined system, phosphate-based conversion film and a hybrid sol-gel coating, were studied in order to prevent the corrosion of a cast magnesium Elektron21 alloy. First, the general metallographic characteristics of this alloy were studied. Second, the morphology of the sol-gel coating, and the conversion layer, was separately investigated. Finally, the properties of the combined system of conversion layer and sol-gel coating were analyzed by electrochemical and physical-chemical techniques and results were discussed taking into account the requirements of such a system.

\section{Experimental}

\subsection{Materials}

The substrate used in this work was a cast Elektron21 magnesium alloy (composition on Table 1), provided by Fondérie Messier (France). After casting into ingots, the El21 alloy was machined to obtain samples with dimensions of $40 \times 20 \times 6 \mathrm{~mm}$.

These metallic samples were initially degreased with acetone before polishing with a SiC paper up to grade \#1200, and then rinsed with ethanol and dried with a stream of air. After polishing, the magnesium substrates were etched in $20 \mathrm{~g} \mathrm{~L}^{-1}$ of nitric acid $\left(\mathrm{HNO}_{3}\right)$, for 2 min at room temperature, rinsed with ethanol and dried with compressed air.

The conversion layer was then formed on etched substrates by immersion in phosphoric acid $\left(\mathrm{H}_{3} \mathrm{PO}_{4}\right)$ at different concentrations, 0.5, $1,3,5$ and $10 \mathrm{~g} \mathrm{~L}^{-1}$ for $2 \mathrm{~min}$, at $25{ }^{\circ} \mathrm{C}$, followed by rinsing with deionized water, ethanol, and finally air-drying at room temperature.

The sol-gel coating was produced by mixing starting precursors consisting of 3-glycidyloxypropyl-trimethoxysilane (GPTMS) and aluminum-tri-sec-butoxide (ASB), deionized water and propanol in a molar ratio of $2: 1: 1: 10$. The resulting mixture was stirred for $2 \mathrm{~h}$ and matured for $24 \mathrm{~h}$ at room temperature before application on the magnesium substrates. The $\mathrm{pH}$ of the sol was 4.1. The sol-gel films were obtained by dip-coating procedure, with controlled withdrawal speed of $200 \mathrm{~mm} \cdot \mathrm{min}^{-1}$, followed by drying at $50{ }^{\circ} \mathrm{C}$ for $2 \mathrm{~h}$ and curing at $110^{\circ} \mathrm{C}$ for $3 \mathrm{~h}$.

\subsection{Characterization techniques}

The morphology of the El21 substrate and coatings was analyzed by scanning electron microscopy (SEM) with a JEOL JSM-6510LV microscope, using an operating voltage of $20 \mathrm{kV}$. Optical microscopy images where obtained using a Keyence VHX-1000E microscope. The surface of the sol-gel coatings was sputter-coated with gold in order to allow their observation with the optical microscope, since these coatings are naturally transparent. The light-source of the microscope was switched to a "light-shift mode" to perform observations at different incidence angles. Electrochemical impedance spectroscopy and open circuit potential (OCP) were performed in $0.05 \mathrm{M}$ $\mathrm{NaCl}$ at room temperature, using a Bio-Logic SP-150 potentiostat. The measurements were performed using a one-chamber threeelectrode cell. The working electrode consisted of an exposed area of $2 \mathrm{~cm}^{2}$. The reference and auxiliary electrode consisted on a saturated calomel electrode (SCE) and a platinum foil electrode, respectively. The EIS spectra were drawn using a potentiostatic mode in

Table 1

Chemical composition of the cast Elektron21 magnesium alloy used in this work.

\begin{tabular}{lllllll}
\hline Elektron21 & & & & & & \\
\hline Element & Nd & Gd & Zr & Zn & Other rare earths & Mg \\
Wt.\% & 3.1 & 1.7 & 1 & 0.5 & $<0.4$ & Balance \\
\hline
\end{tabular}

the frequency range from $65 \mathrm{kHz}$ to $10 \mathrm{mHz}$, with an applied voltage of $10 \mathrm{mV}$ vs. OCP. The surface roughness was evaluated by white-light source interferometry, using a Zygo-Instruments New View 100 apparatus. Three samples were analyzed on each characterization technique in order to check the reproducibility of the tests.

\section{Results and discussion}

\subsection{Pretreatment of the magnesium El21 substrate}

Polishing was applied in order to obtain a similar surface for all the samples, because after machining (as-received), their surfaces were completely different from one to each other. After polishing, the obtained average roughness $\left(R_{a}\right)$ evaluated for all the samples was $0.13 \mu \mathrm{m}$.

In order to clean the surface, the substrate was etched with $\mathrm{HNO}_{3}$ (Fig. 1a). After that, the microstructure of the alloy is revealed, which presents an average grain size of $80 \pm 20 \mu \mathrm{m}$. However, the surface roughness $\left(R_{a}\right)$ considerably increases $(0.55 \mu \mathrm{m})$. Also, the presence of agglomerates (white) in relief at the surface may be seen.

The EDX analysis of this surface shows three main regions with different compositions, one corresponding to the grains of magnesium, the second to the grain boundaries of neodymium, and the third one to the agglomerates (or compounds) of zirconium. The alloying elements gadolinium and zinc are distributed homogeneously on the magnesium alloy. The cross-section image (Fig. 2) of the surface of El21 alloy after mechanical polishing and chemical etching shows the morphology of agglomerates rich on neodymium and zirconium.

\subsection{Sol-gel coating without conversion film}

First of all, during the preparation of sol-gel films by dip-coating, an active production of gas at the surface of the El21 alloy samples was observed, when they were immersed in the sol. This indicates that a chemical reaction took place between the magnesium alloy and the sol, reflecting the high degree of reactivity of this alloy.

The hybrid coatings are naturally transparent, and to perform the observation of the coating surface by optical microscopy, the coated samples were gold-coated. It is possible to observe that the coating presents a heterogeneous morphology, with several defects, with a size in the range of 30-100 $\mu \mathrm{m}$ (Fig. 3a). The light-source of the optical microscope consists on a ring that provides illumination of the sample. By switching between full-ring illumination and half-ring illumination, it is possible to observe the objective at different angles of reflection, since there is a change on the incidence angle of light. The images shown in Fig. 3a and b were taken at the same spot of the sample, and they correspond to the surface of the hybrid sol-gel coating and the El21 alloy surface, respectively. Fig. 3b clearly shows the magnesium grains, and the neodymium and zirconium compounds (black points, with light-gray surrounding area). Compared to Fig. 3a, it may be seen that the defects on the hybrid sol-gel coating are located at the same position of the neodymium and zirconium compounds of the El21 alloy. The white arrow on the image marks the location of a defect on the hybrid sol-gel film, which coincides with the location of the Nd grain boundary on the substrate. Other defects can be also identified on the sol-gel hybrid film, and their location coincides with the typical position of $\mathrm{Zr}$ or $\mathrm{Nd}$ compounds.

A SEM image of the sample shows the morphology of the surface of the hybrid sol-gel coating, where the presence of many nodules and pits at the surface can be identified (Fig. 4). The cross-section of the sample (Fig. 5) shows that the thickness of the coating is around $5 \mu \mathrm{m}$. A difference of thickness on the coating between the intragranular zone of magnesium and the compounds of the alloy may be seen. It may be seen that the neodymium compounds remain at the same level of the magnesium grains. However, the yellow square on the left image indicates the position of a protuberance that emerges 
(a)

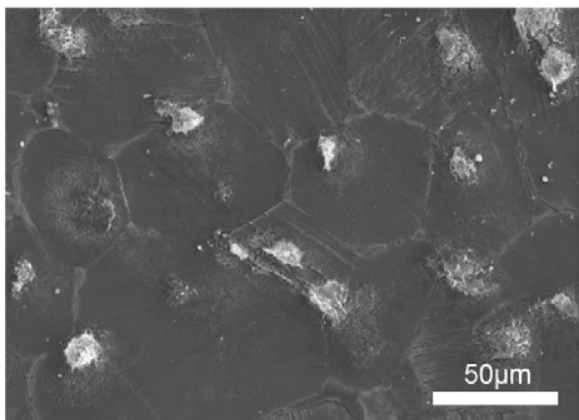

(b)

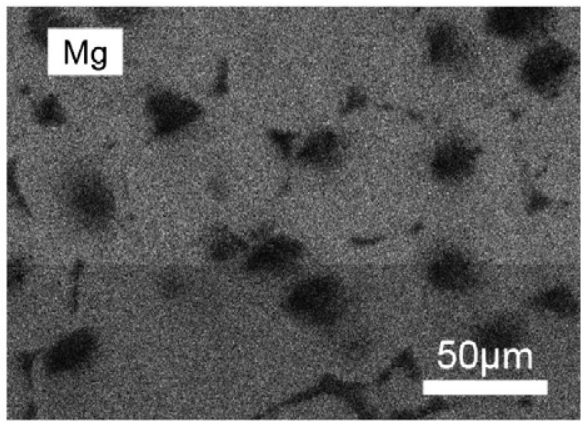

(c)
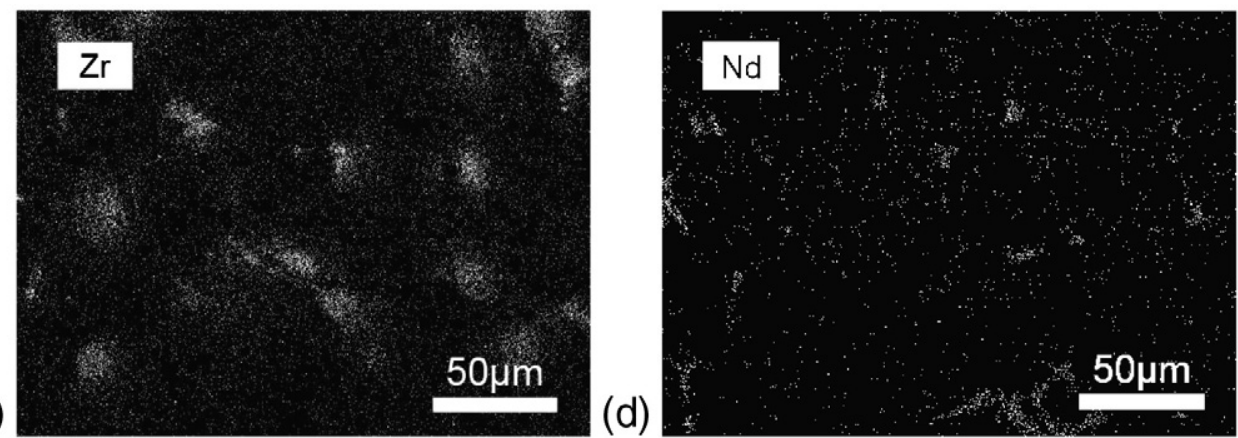

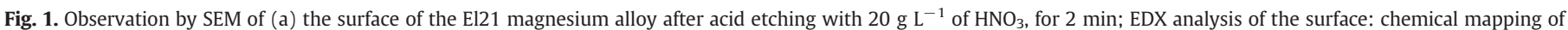
(b) $\mathrm{Mg}$; (c) Nd and (d) Zr.

from the substrate, which disrupts the continuity of the hybrid sol-gel film.

Fig. 5b shows a SEM image obtained on a backscattered electron composition mode (BSE), in order to differentiate the present elements: the magnesium substrate (light-gray), the hybrid coating (gray), the neodymium and zirconium compounds (white), and the resin (dark-gray). The thickness of the hybrid film is lower compared to the rest of the surface at the location of the protuberance. Inside the hybrid coating, the existence of bubbles (black) that suggests the presence of defects caused by occluded gas on the hybrid solgel coating may be seen. Fig. $5 \mathrm{c}$ is a chemical mapping obtained by EDX analysis at the same zone of the BSE image, showing that the white shape on the BSE image next to the protuberance suggests a neodymium compound, here in yellow. We note the presence of zirconium in the region corresponding to the protuberance, with some smaller particles at the top of it and the discontinuity of the hybrid coating.

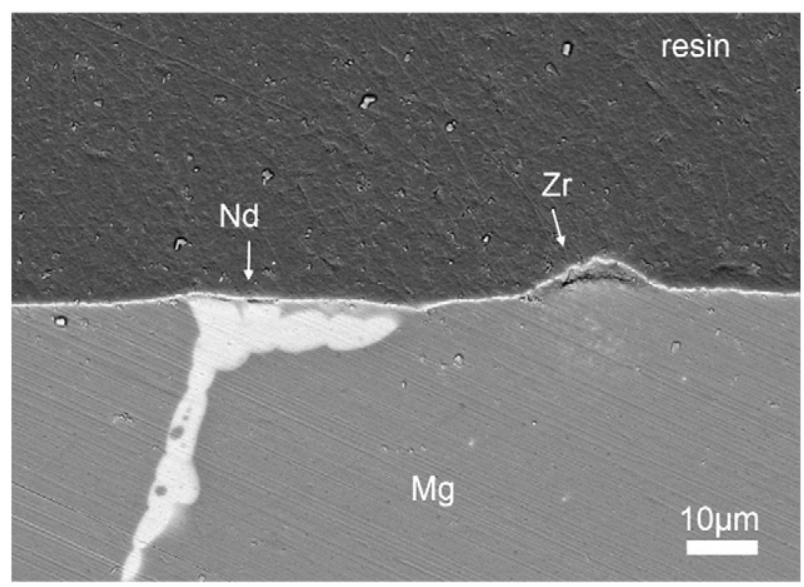

Fig. 2. SEM cross-section image of the El21 alloy after mechanical polishing and chemical etching with $20 \mathrm{~g} \mathrm{~L}^{-1}$ of $\mathrm{HNO}_{3}$, for $2 \mathrm{~min}$.
Despite the good leveling effect of the hybrid sol-gel coating, often reported in the literature on several metallic alloys [33], on El21 casted alloy, these defects are not covered by the hybrid coating. Moreover, the presence of bubbles in the coating suggests a reactivity of the substrate with the sol during the immersion. These defects seem to have its origin on the microstructure of the cast El21 alloy and especially where the intermetallic compounds of neodymium and zirconium-rich are located [43].

This work proposes the use of an intermediary conversion layer of magnesium alloy, combined with a hybrid sol-gel film. This layer was produced by the treatment of the samples with phosphoric acid, in order to form phosphate-based compounds, chemically more stable than the magnesium metallic surface $[8,10,11,14]$. The characteristics of the produced conversion layers are described hereinafter.

\subsection{Conversion layer}

The OCP of the El21 samples was recorded during immersion into the $\mathrm{H}_{3} \mathrm{PO}_{4}$ bath (Fig. 6). Between 0.5 and $3 \mathrm{~g} \mathrm{~L}^{-1}$ of $\mathrm{H}_{3} \mathrm{PO}_{4}$, the potential slightly grows to positive values. On the other hand, with a concentration of $10 \mathrm{~g} \mathrm{~L}^{-1}$ of $\mathrm{H}_{3} \mathrm{PO}_{4}$, the potential considerably increases during the first $30 \mathrm{~s}$, followed by a steady increase to the end of the immersion. Also, it may be underlined that the obtained potential is higher at $10 \mathrm{~g} \mathrm{~L}^{-1}$ of $\mathrm{H}_{3} \mathrm{PO}_{4}$, which is related to the growth of a thicker phosphate layer.

Fig. 7 shows a SEM image of the surface of the samples after conversion treatment. The development of a conversion layer by interaction with the magnesium-rich grains can be seen. The influence of the microstructure and chemical composition of the alloy on the formation of phosphate-based films was also observed by W. Zhou [10] for the AZ91D magnesium alloy. They showed that the appearance of the phosphate layer is different in both cases: the $\alpha$-phase (rich on $\mathrm{Mg}$ ) and the $\beta$-phase (rich on $\mathrm{Al}$ ). In the case of the El21 alloy, the magnesium region is much more reactive than the neodymium or zirconium compounds. The composition of other phosphate conversion layers has been studied by other authors by EDS, establishing that they are mainly constituted of phosphates, oxides and hydroxides $[9,14]$. 

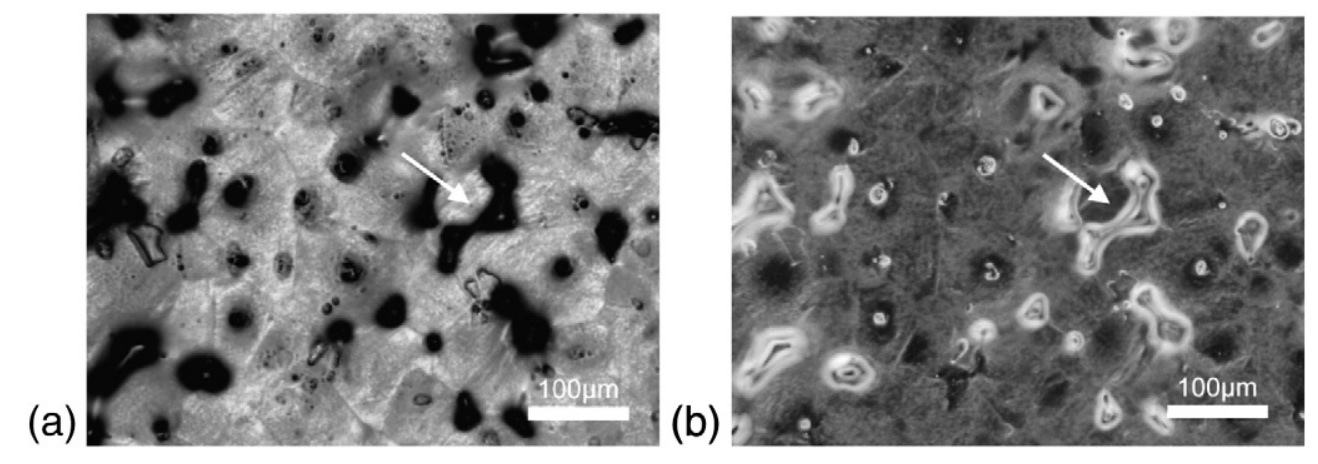

Fig. 3. Optical microscope images of the sol-gel coating applied on the El21 cast alloy after acid etching. (a) Normal mode; (b) light-shift mode.

Like for the micrograph of the etched surface of the El21 alloy (Fig. 1a), whatever the $\mathrm{H}_{3} \mathrm{PO}_{4}$ concentration of the conversion bath, we can observe protuberances at the surface of grains corresponding to the presence of zirconium compound while the neodymium at grain boundaries is only recovered by a thin conversion film. The presence of an area rich in zirconium seems favorable to a strong local reactivity. It is important to notice that the concentration of the bath $\mathrm{H}_{3} \mathrm{PO}_{4}$ influences the morphology of the conversion layer. For lower $\mathrm{H}_{3} \mathrm{PO}_{4}$ concentrations, the film covers the magnesium grains without apparent cracks. At concentrations superior to $3 \mathrm{~g} \mathrm{~L}^{-1}$ the apparition of cracks is observed, attributed to the higher thickness of the layer and to internal stresses generated during the drying of the hydrated conversion film. With a concentration of $10 \mathrm{~g} \mathrm{~L}^{-1}$ of $\mathrm{H}_{3} \mathrm{PO}_{4}$, the phosphate film shows wide cracks with an identical length to the grain size. Cracks must be avoided when the purpose is to use this conversion film as a bond coat for additional coatings, like sol-gel coatings or paints. Using lower concentrations of $\mathrm{H}_{3} \mathrm{PO}_{4}$ decreases the number of cracks.

The cross-section image of the samples in a BSE mode is shown in Fig. 7. The images allow to identify the magnesium grains (light-gray), the neodymium compounds (white), the phosphate conversion film (gray), and the resin (dark-gray). Here, the neodymium compounds seem attacked at a lower speed than the magnesium grains, and the phosphate layer grew consuming the magnesium grains, as what commonly occurs in the chemical conversion phenomena. It may be seen that the thickness of the conversion layer increases with the concentration of the $\mathrm{H}_{3} \mathrm{PO}_{4}$ bath. Fig. 8 plots the thickness of the conversion layer obtained at the different concentrations of $\mathrm{H}_{3} \mathrm{PO}_{4}$ tested $\left(0.5,1,3\right.$ and $\left.10 \mathrm{~g} \mathrm{~L}^{-1}\right)$. This relationship between thickness and the $\mathrm{H}_{3} \mathrm{PO}_{4}$-concentration may be due to the concentration of $\mathrm{PO}_{4}^{3-}$ anions from the phosphoric acid available to react with the $\mathrm{Mg}^{2+}$ cations from the substrate. Both reactions, the dissolution of the metallic substrate and the formation of the conversion layer are in competition. The reactions that form magnesium phosphate, $\mathrm{Mg}_{3}\left(\mathrm{PO}_{4}\right)_{2}$, have better performances and speed at higher concentration of $\mathrm{H}_{3} \mathrm{PO}_{4}$ than the dissolution of the magnesium substrate. This may explain the thickness increment of the phosphate conversion layer with the concentration of the phosphoric acid treatment.

\subsection{Duplex system: conversion layer and sol-gel coating}

During the dip coating of the El21 magnesium alloy with $\mathrm{H}_{3} \mathrm{PO}_{4}$ conversion layer in the sol, the emission of gas observed at the surface of the substrates, was in lower proportions compared to the samples without a conversion layer. Hence, the reactivity of the magnesium substrate was partially reduced by the presence of the phosphate conversion layer. Fig. 9 shows an optical image of the surface of the duplex system: conversion layer/sol-gel coating. The surface of the duplex system presents the same defects of the hybrid coating produced without a conversion film. The location of defects (lighting in normal incidence, black areas in Fig. 9a) coincides with the emplacement of the zirconium and neodymium compounds of the El21 alloy (white areas, Fig. 9b).

Fig. 10a shows a SEM image of the surface of the samples treated with $10 \mathrm{~g} \mathrm{~L}^{-1} \mathrm{H}_{3} \mathrm{PO}_{4}$ and coated with the hybrid film. It may be seen that the sol-gel coating is transparent enough to electrons to reveal the microstructure of the underlying substrate. Fig. 10b shows a cross-section of this system. The conversion layer is around $2 \mu \mathrm{m}$ thick, and the hybrid coating $5 \mu \mathrm{m}$ thick. Likewise, the phosphate film presents many cracks, in accordance with the previous observations (Fig. 7) and the hybrid coating seems to fill the discontinuities of the conversion film. However, the auto-leveling effect of the dip-coating process is not confirmed here, since the neodymium compounds and the zirconium ones appear in relief in respect to the rest of the coating.

\subsection{Electrochemical measurements}

\subsubsection{Open circuit potential}

Fig. 11 shows the open circuit potential for the samples recorded during the immersion time in the $0.05 \mathrm{M} \mathrm{NaCl}$ corrosive solution. (a)

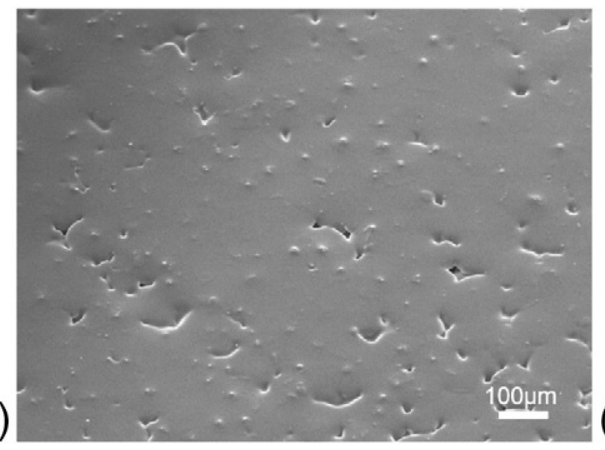

(b)

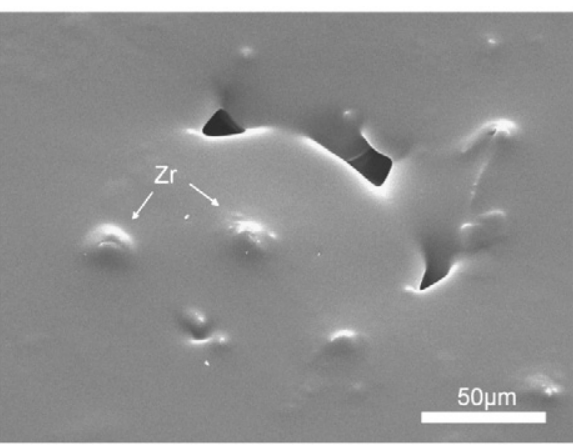

Fig. 4. SEM image of the El21 cast alloy coated with the hybrid sol-gel film: (a) $100 \times$ (b) $500 \times$. 


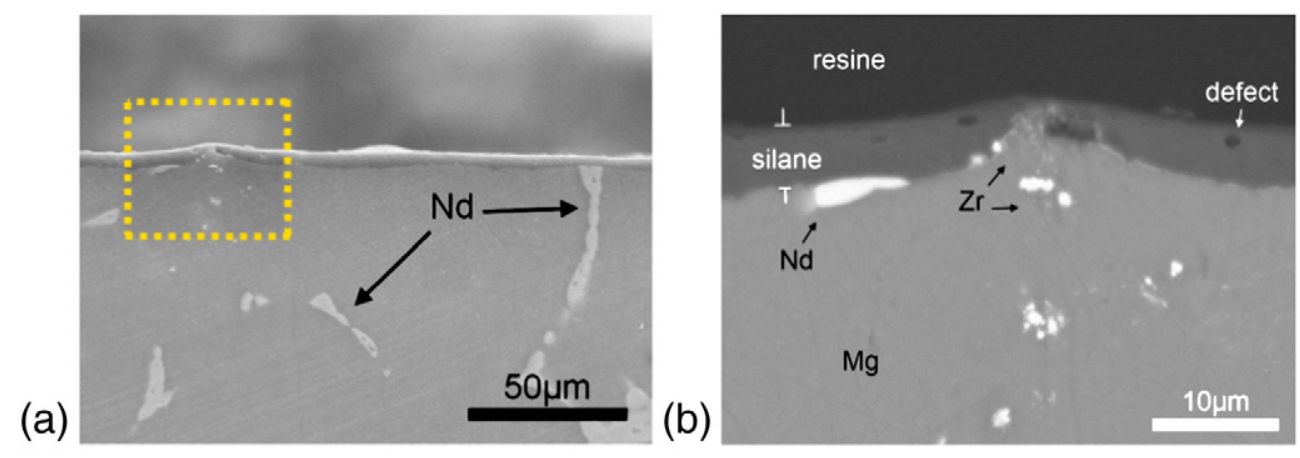

(a)

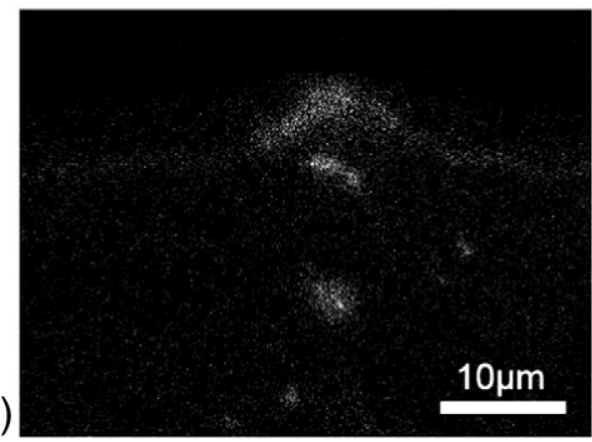

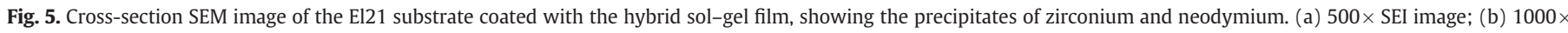
BEC image; (c) EDX analysis.

The curves correspond to the bare substrate of El21, the hybrid film and the duplex system: conversion layer $\left(10 \mathrm{~g} \mathrm{~L}^{-1}\right.$ of $\left.\mathrm{H}_{3} \mathrm{PO}_{4}\right)+-$ hybrid film.

During the first minutes of immersion, the potential of bare El21 substrate becomes strongly negative. This phenomenon results from the depassivation of magnesium by dissolution of the natural oxidized layer present at the surface of the samples. After that, it becomes nobler with time, in reason of the natural passive layer generated at the surface by the reaction between the alloy and the electrolyte. This passive layer, mainly constituted of magnesium oxide and hydroxide [1,44], temporarily delays the dissolution rate of the metallic substrate and offers a primary protection against corrosion.

On the other hand, the potential for the hybrid coated samples (with and without conversion layer) started with a more positive potential than the bare El21 substrate, and remains steady up to the end of the immersion. However, the potential oscillates in short periods of time indicating that the interface substrate-electrolyte is subject to disturbing phenomena, attributed to chemical reactions generated

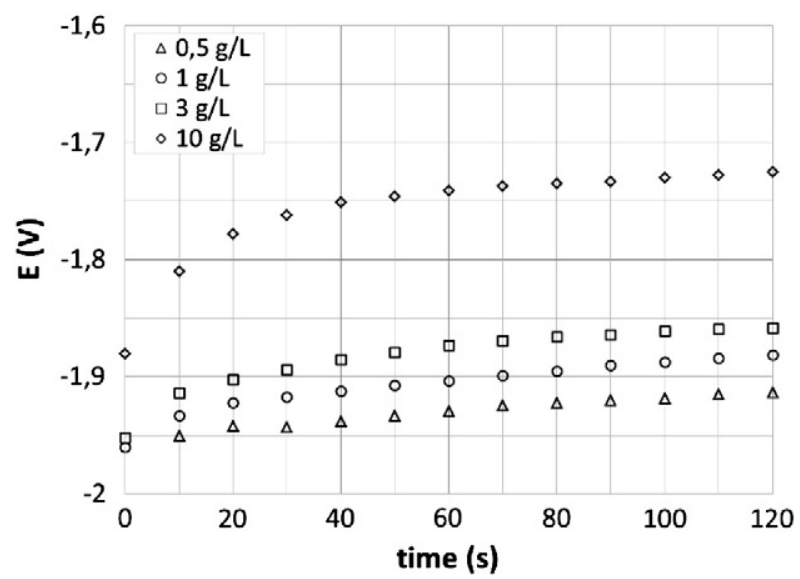

Fig. 6. OCP measurements during immersion of the El21 alloy in the $\mathrm{H}_{3} \mathrm{PO}_{4}$ bath at different concentrations. between the magnesium substrate and the corrosive solution. This means that the barrier effect of the hybrid coating is limited, and exhibits some permeability for the electrolyte. However, in the first time of immersion (10 $\mathrm{min}$ ), we can notice the nobler potential of the duplex system than the single hybrid one.

\subsubsection{Electrochemical impedance spectroscopy}

3.5.2.1. Magnesium substrate. The EIS spectra for the uncoated El21 magnesium alloy after pretreatment are shown in Fig. 12. Two time constants can be observed in the Bode phase diagram (Fig. 12a), the first located in the middle frequency range $(15 \mathrm{~Hz})$, and the second one in the low frequency region $(126 \mathrm{mHz})$. Correa et al. [37] propose an interpretation of similar diagrams obtained for the AZ91 magnesium alloy. On his work, two time constants appear at the same range of frequencies, one at $144 \mathrm{~Hz}$, and the second at $388 \mathrm{mHz}$. The first time constant is associated to the passive film of the substrate, as it shows a capacitive character due to its phase angle. In addition, the film does not cover the entire surface of the substrate which can induce a faradic process. This layer is mainly composed of magnesium oxide and hydroxide $[44,45]$. The time constant at low frequency is considered as a resistive behavior created by the corrosion process.

A different interpretation indicates that the time constant located in the middle frequency range $(\sim 10 \mathrm{~Hz})$ is attributed to the capacitance of the electrochemical double layer at the interface metal/electrolyte. In fact, the presence of a time constant in the high frequency range (20 kHz), which increases its phase angle with the immersion time, is attributed to the growth of the $\mathrm{Mg}(\mathrm{OH})_{2}$ film [46].

Nevertheless, the obtained Bode phase diagrams on this work do not exhibit a time constant in the high frequency range, so the middle frequency time constant is considered as the capacitance of the passive layer. The impedance modulus (Fig. 12b) shows a slight increase of the polarization resistance as a function of time at the low frequency range, due to the development of the oxide/hydroxide layer and deposition of corrosion products. The value of the impedance modulus for the bare El21 alloy after $192 \mathrm{~h}$ of immersion in the corrosive solution is $3.5 \mathrm{kohm} \cdot \mathrm{cm}^{2}$. 

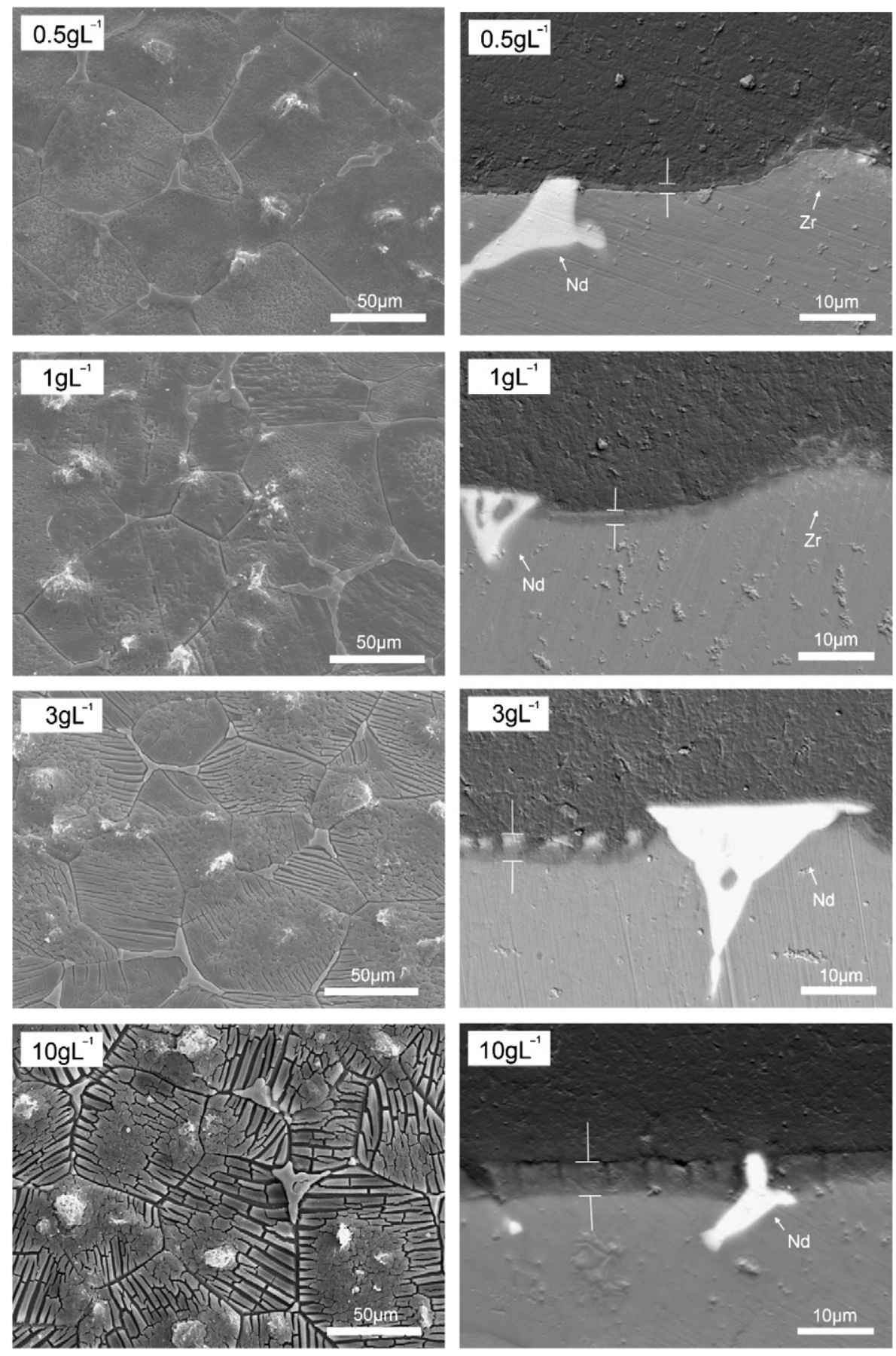

Fig. 7. SEM images of the surface (SEI) and cross-section (BSE mode) of the phosphate based conversion coating formed with different concentrations of $\mathrm{H}_{3} \mathrm{PO}_{4}$.

3.5.2.2. Duplex system: conversion layer and sol-gel coating. Fig. 13 shows the EIS plots for the El21 substrate coated different protection systems, after $192 \mathrm{~h}$ of immersion in the corrosive solution. The Bode phase diagram (Fig. 13a) shows three time constants for all the protective systems, the first at high frequency $(10 \mathrm{kHz})$, the second in the low frequency region $(100 \mathrm{~Hz})$, and the third one in the low frequency range $(0.1 \mathrm{~Hz})$. The high frequency time constant can be attributed to the capacitance of the hybrid sol-gel coating. The second time constant at middle frequency $(100 \mathrm{~Hz})$, may be ascribed to the intermediate layer present at the interface metal/hybrid film, constituted by both the phosphate conversion layer and corrosion products. The time constant at low frequency suggests the relaxation process of absorbed species at the interface substrate/electrolyte [22,36,46,47]. It may be seen that the impedance modulus at low frequency is inferior for the hybrid sol-gel coating compared to any of the duplex systems, proving the beneficial effect of the conversion layer. Also, it may be seen that the value of the impedance modulus is higher as the concentration of $\mathrm{H}_{3} \mathrm{PO}_{4}$ increases.

The duplex system treated with $10 \mathrm{~g} \mathrm{~L}^{-1}$ of $\mathrm{H}_{3} \mathrm{PO}_{4}$ shows the best results on EIS (phase angle and impedance modulus) after $192 \mathrm{~h}$ of immersion, compared to the rest of the protection systems. The Bode phase diagram (Fig. 14a) shows two time constants at the beginning of the immersion $(1 \mathrm{~h})$, at high and low frequencies (10 $\mathrm{kHz}$ and $80 \mathrm{mHz}$, respectively). These capacitive responses can be related to the sol-gel film, and the relaxation process of absorbed species, respectively. After $24 \mathrm{~h}$ of immersion, the high frequency time constant considerably reduces its phase angle, related to electrolyte incorporation that decreases the barrier properties of the hybrid 


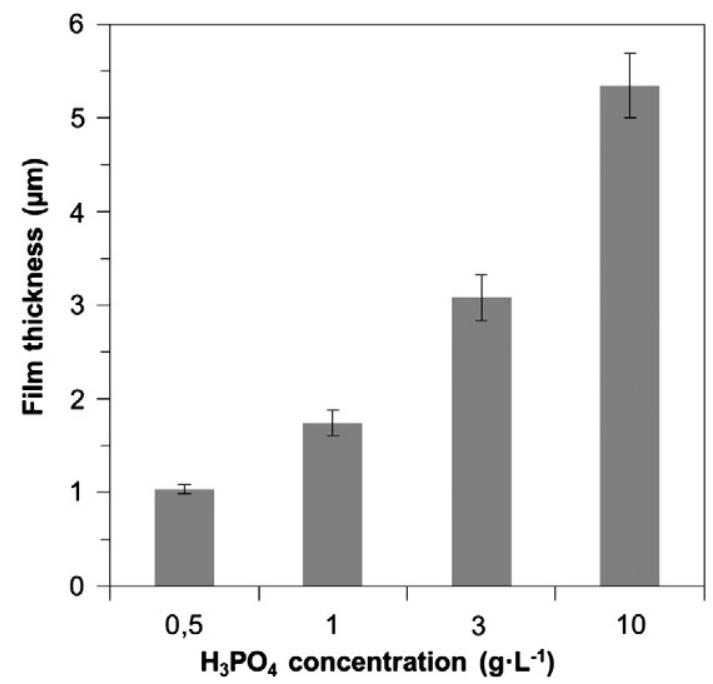

Fig. 8. Thickness of the phosphate conversion coating as a function of the $\mathrm{H}_{3} \mathrm{PO}_{4}$ concentration.

sol-gel coating. Likewise, the appearance of a second time constant at the middle frequency range $(126 \mathrm{~Hz})$ is attributed to the presence of an intermediate mixed layer, consisting of the conversion layer and corrosion products, located between the hybrid sol-gel coating and the magnesium substrate. Both time constants are visible on the following hours of immersion, but the high frequency constant gradually decreases its phase angle. The apparition of the second time constant after $24 \mathrm{~h}$ of immersion is afforded to the liquid take of the sol-gel hybrid film which finally gets in contact with the metallic substrate. The frequency range and the value of its phase angle are very similar to those of the bare substrate. This suggests that this intermediate layer has the same morphological nature of the passive layer developed by bare substrate, both consisting of a porous-ceramic layer. The impedance modulus shows a substantial reduction between $1 \mathrm{~h}$ and $24 \mathrm{~h}$ of immersion, slightly decreasing to the end of the immersion. After $192 \mathrm{~h}$ of immersion, the impedance modulus of the duplex system conversion $\left(10 \mathrm{~g} \mathrm{~L}^{-1}\right)$ /hybrid film is around $40 \mathrm{kohm} \cdot \mathrm{cm}^{2}$.

Fig. 15 shows the cross-section SEM images on a BSE composition mode of the samples at the end of the immersion (192 h) in $0.05 \mathrm{M}$ $\mathrm{NaCl}$. Fig. 15a corresponds to the El21 substrate coated with the hybrid sol-gel film. On the figure, it is possible to identify the magnesium substrate, the corrosion products and the hybrid sol-gel coating. Some fragments of neodymium compounds inside the corrosion products, which suggest that these neodymium compounds possess a better resistance against corrosion than the magnesium grains may be seen. This is in good accordance with the results obtained by Chang et al. [43], where the eutectic compound $\mathrm{Mg}_{12} \mathrm{Nd}$ of a similar magnesium alloy $(\mathrm{Mg}, 3 \mathrm{Nd}, 0.2 \mathrm{Zn}, 0.4 \mathrm{Zr}$, wt.\%) remained unaffected after $72 \mathrm{~h}$ of immersion in $5 \% \mathrm{NaCl}$. Moreover, the corrosion pits grow under the hybrid sol-gel coating consuming mainly the magnesium grains, lifting up the hybrid sol-gel coating.

Fig. 15b shows duplex system at the end of the EIS tests. The presence of the conversion layer formed with $10 \mathrm{~g} \mathrm{~L}^{-1}$ of $_{3} \mathrm{PO}_{4}$ can be identified, as well as the corrosion products that formed under the duplex system. It is to notice that the conversion layer is in direct contact with the corrosion products, and both materials should have been exposed to the corrosive solution. However, only the metallic magnesium grains were transformed into corrosion products. This means that the conversion layer has a better chemical stability than the metallic magnesium grains, since it remained preserved after contact with the corrosive solution. These observations suggest that the conversion layer offers additional corrosion resistance and protection combined with the hybrid sol-gel coating.

Usually, the corrosion pits appear at the spot of defects on the protective coating, where the aggressive species have access to the substrate, progressively growing with time as they consume the metallic substrate. The aggressiveness of $\mathrm{Cl}^{-}$ions for magnesium alloys is well known, which promotes the pitting corrosion [48]. Another typical way of pitting is the galvanic reactions created by the alloying phases of metallic substrates. The micro-galvanic cells perform an exchange of charges at their boundaries, due to their potential difference. When external agents, like liquids, get in contact with a metallic surface, the micro-galvanic cells promote the reaction between the substrate and the corrosive agents.

Many works report the influence of the rare earth content on the corrosion behavior of magnesium alloys. The addition of neodymium or/and gadolinium modifies the microstructure of the magnesium alloys (AZ91D, AM50) reducing the portion of $\beta-\mathrm{Mg}_{17} \mathrm{Al}_{12}$ phase, and so the micro-galvanic couples with the $\alpha-\mathrm{Mg}$ matrix [49,50]. Also, in the case of the hot extruded AZ91 alloy, a decrease of the density of twins and dislocations on the microstructure is observed by increasing the Nd content [51]. Furthermore, the anticorrosion properties of a cast AZ91 alloy were substantially improved by the addition of rare earths (Ce, La, Nd and Pr), at the same time that the mechanical properties of the alloy increased [52].

The influence of the zirconium content on a magnesium alloy has been reported by Chang et al. [43]. The authors compare two different alloys, one containing $0.4 \mathrm{wt} . \%$ of $\mathrm{Zr}$, and the second one without $\mathrm{Zr}$. The microstructure of the $\mathrm{Zr}$ containing alloys was similar to that of the El21 alloy, both presenting zirconium-rich cores at the center of the magnesium grains. Lower corrosion rates were obtained for these alloys, attributed to the formation of a more compact and protective film, compared to those without zirconium.

However, the observations on this work show that the zirconium compounds of the El21 alloy represent an important source of morphologic defects for the anticorrosion hybrid sol-gel treatment (Fig. 3). The possible influence of these compounds may be based on two reasons: the first, the height of the zirconium compounds (a)

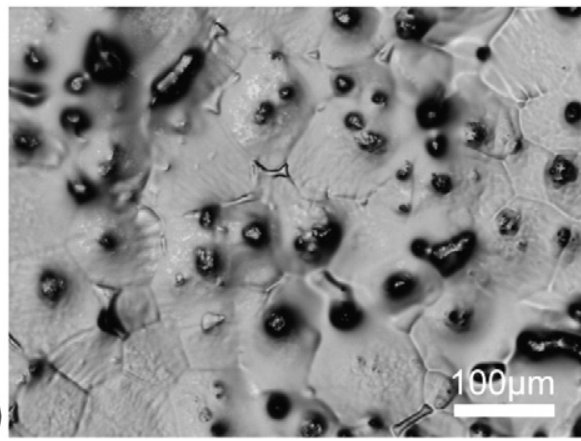

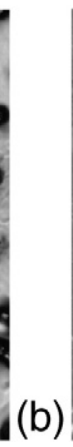

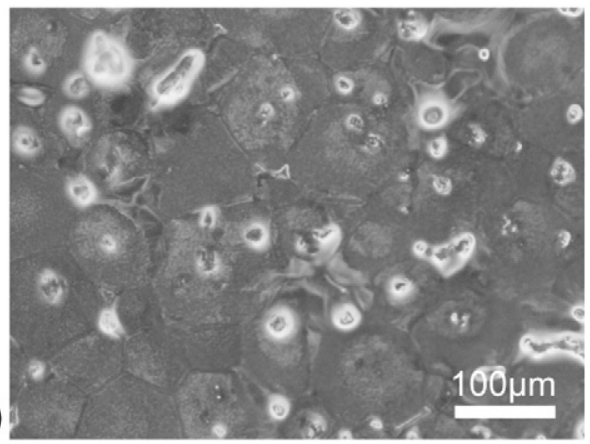

Fig. 9. Optical image of the sol-gel coating applied on the El21 alloy after treatment with $10 \mathrm{~g} \mathrm{~L}^{-1}$ phosphoric acid. (a) Normal mode; (b) light-shift mode. 

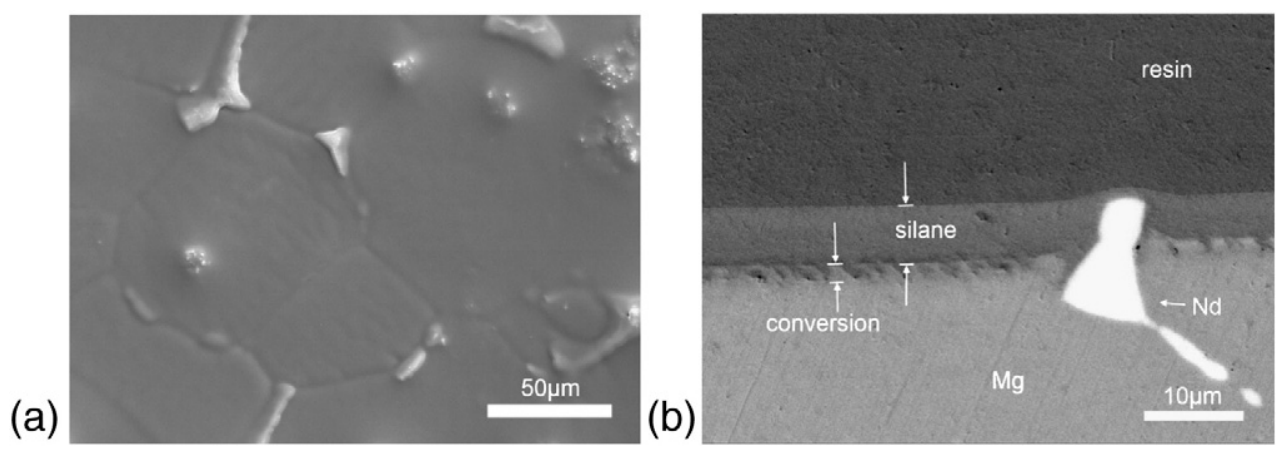

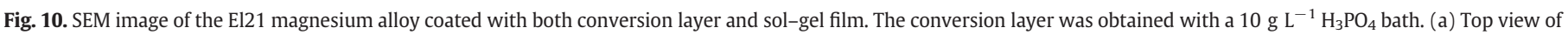
the coating (SEI mode); (b) cross-section view (BSE mode).

after acid pretreatment (Figs. 1 and 5) that obstructs the covering of the hybrid coating, and induces a partial or heterogeneous coverage area; the second may be attributed to a galvanic system between the zirconium compounds, the magnesium grains and the sol (when it is liquid), which generates a cathodic hydrogen evolution at this point and affects the surface of the hybrid coating during the condensation stage.

The presence of the conversion layer has a positive effect for protection afforded by the hybrid sol-gel treatment, due to the high values of polarization resistance $(\log |\mathrm{Z}|)$ obtained, compared to the single hybrid coating. The low frequency resistance (or polarization resistance, $R_{p}$ ) is considered as the global corrosion resistance of a protective system, like paints or hybrid sol-gel coatings [22,35-37,39,46,53,54]. The resistance of the lone hybrid coating decreases to lower values with time, meaning a faster loss of protective properties. A possible explanation is the difference of thickness between tested systems, the single sol-gel layer $(5 \mu \mathrm{m})$, and the hybrid + conversion layer $(7 \mu \mathrm{m})$. In the case of anticorrosion coatings, thickness is an important parameter, since it determines the distance that separates the substrate from the aggressive environments. The hybrid coating offers a first protection against aggressive species, opposing a barrier effect to keep them off from the substrate. However, hybrid sol-gel coatings present a certain degree of porosity that limits their barrier properties [41,55], partially blocking species with high mobility, like liquids. Thereby, the presence of a second layer within the substrate and the hybrid coating offers an

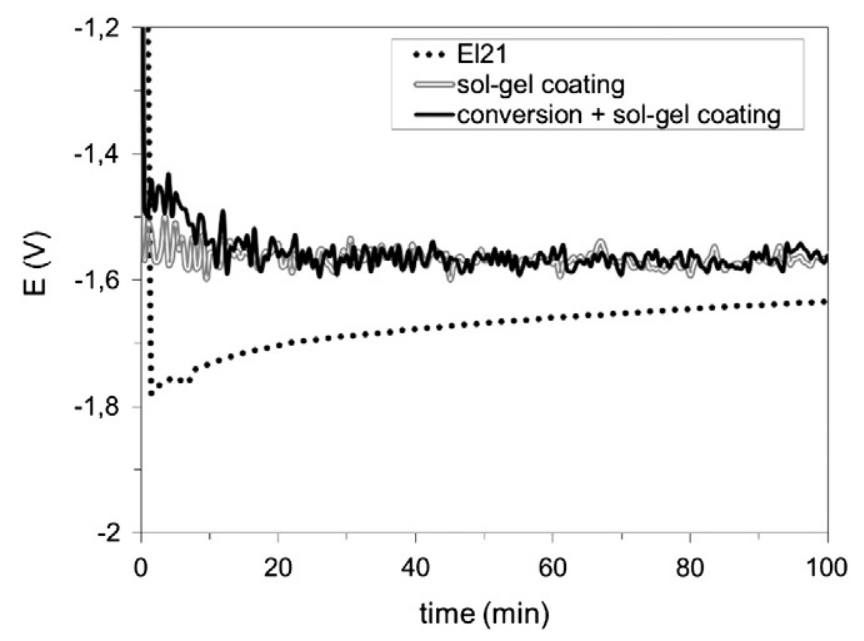

Fig. 11. OCP measurement of the bare El21 substrate after acid etching, coated with the sol-gel film, and coated with both conversion layer and sol-gel film, immersed in $0.05 \mathrm{M} \mathrm{NaCl}$. additional obstacle for the electrolytes, reducing the mobility of corrosive species. Furthermore, the compounds identified on the conversion layers are more chemically stable than the metallic substrate, with generally a high degree of insolubility in water.

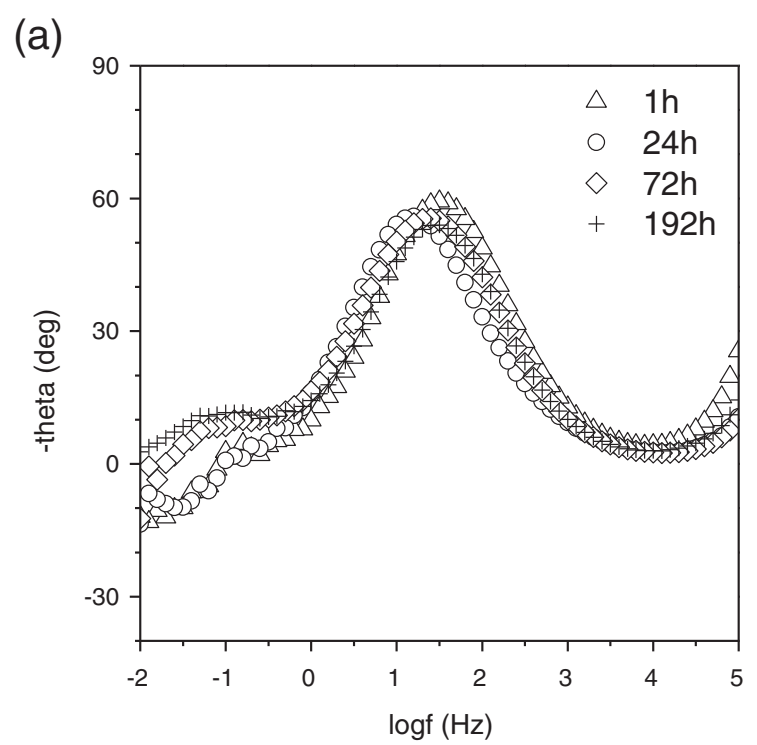

(b)

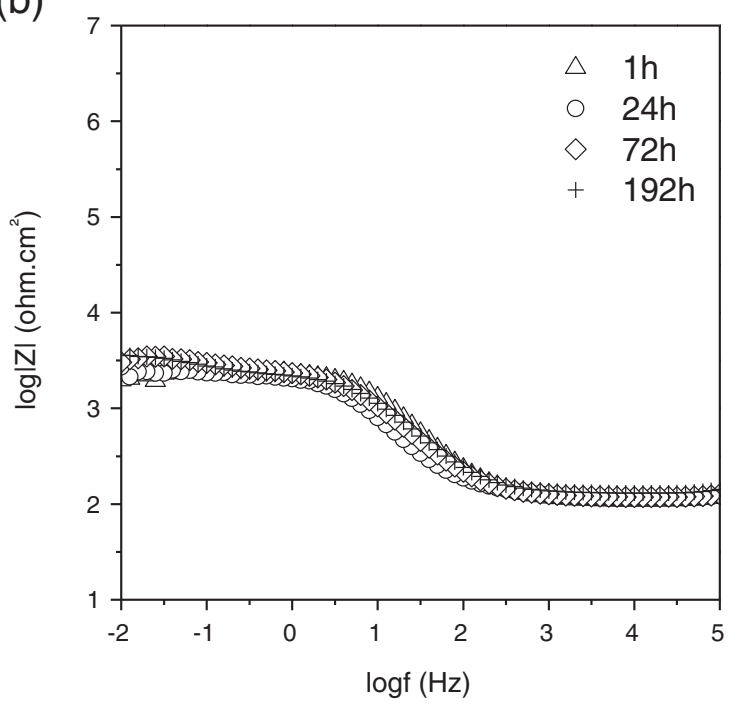

Fig. 12. Bode diagrams of the EIS spectra for the uncoated El21 magnesium alloy substrate after pretreatment, during immersion in $0.05 \mathrm{M} \mathrm{NaCl}$. 
(a)

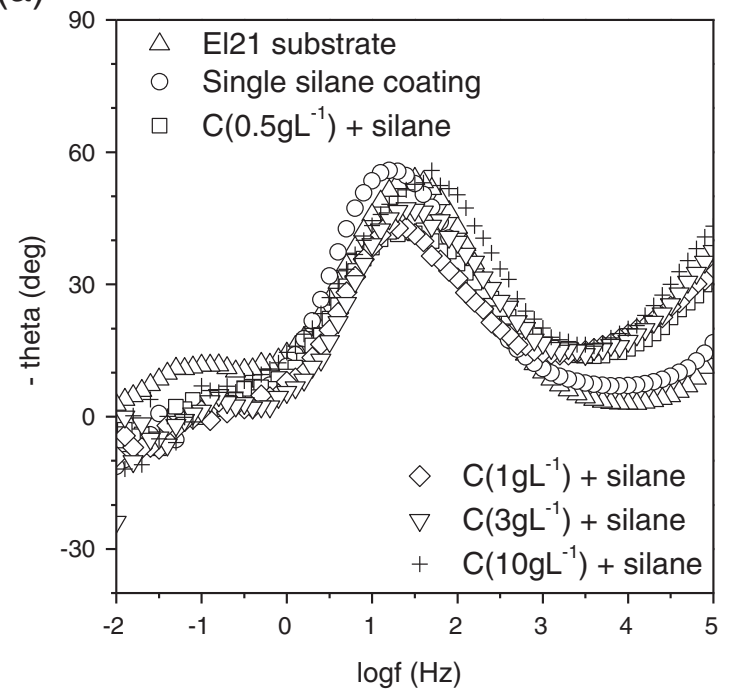

(b)

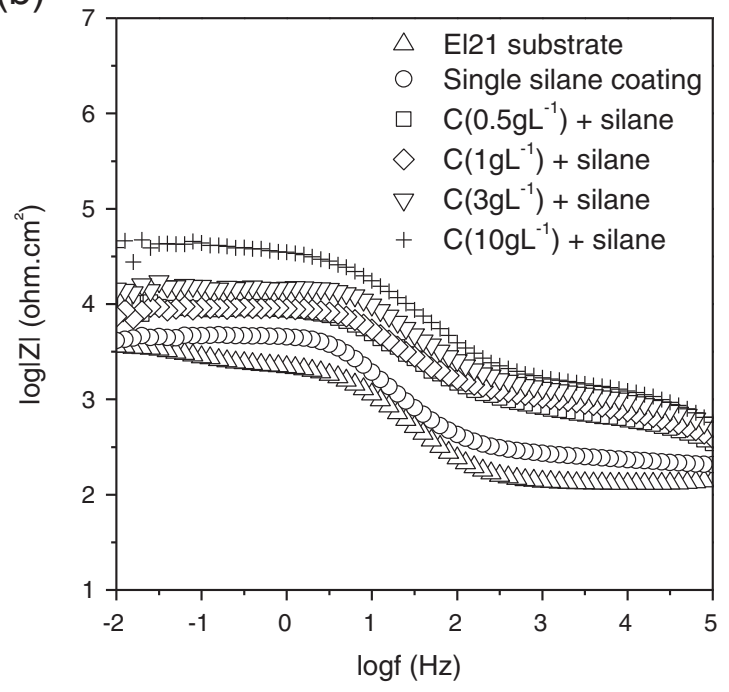

Fig. 13. Bode diagrams of the EIS spectra for the El21 substrate treated with different protection systems, after $192 \mathrm{~h}$ of immersion in $0.05 \mathrm{M} \mathrm{NaCl}$.

\section{Conclusions}

In this study, an anticorrosion duplex system "conversion layer"/"hybrid coating" to protect the El21 magnesium alloy is reported and evaluated. Morphological and electrochemical aspects of the protective systems were analyzed by SEM and EIS techniques. The high reactivity of the El21 magnesium alloy has been taken in evidence because a hydrogen gas production is observed when this alloy gets in contact with the sols. This phenomenon may lead to the formation of defects at the surface of the sol-gel coating. Nevertheless, the single hybrid coating has very interesting properties of anti-corrosion protection, as shown by the EIS results. After $192 \mathrm{~h}$ of immersion in the corrosive solution $(0.05 \mathrm{M} \mathrm{NaCl})$, the impedance modulus of the hybrid coating is superior to that of the bare El21 alloy. However, after $192 \mathrm{~h}$, the protective effect of the hybrid sol-gel film disappears.

The addition of a phosphate based conversion layer before the solgel coating increases the impedance value of resistance of the protective system, with optimal results when the surface of the alloy is pretreated with $10 \mathrm{~g} \mathrm{~L}^{-1}$ of $\mathrm{H}_{3} \mathrm{PO}_{4}$ for 2 min. The impedance modulus of the surface is higher than the single hybrid coating after $192 \mathrm{~h}$ of immersion in the corrosive solution.

Despite the enhancement of the protective properties of the hybrid sol-gel coating by the addition of an intermediate phosphate (a)

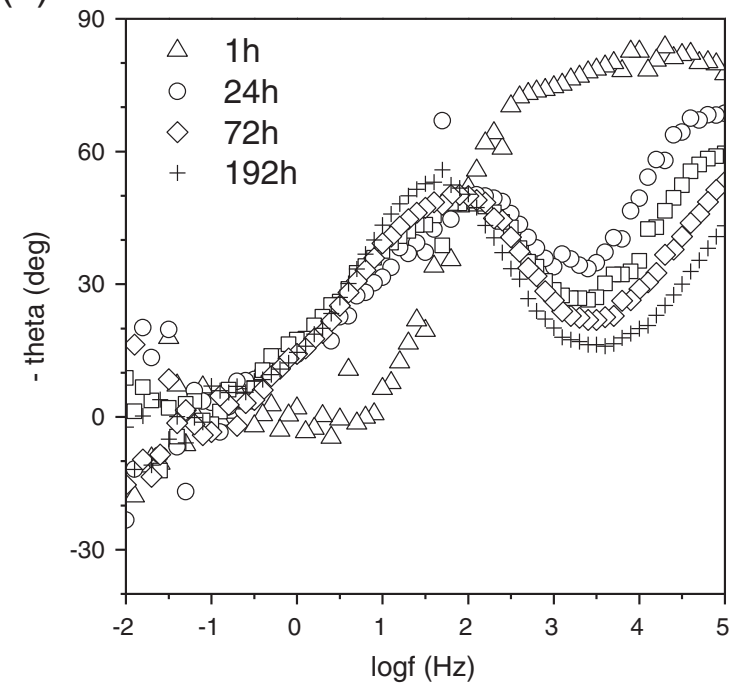

(b)

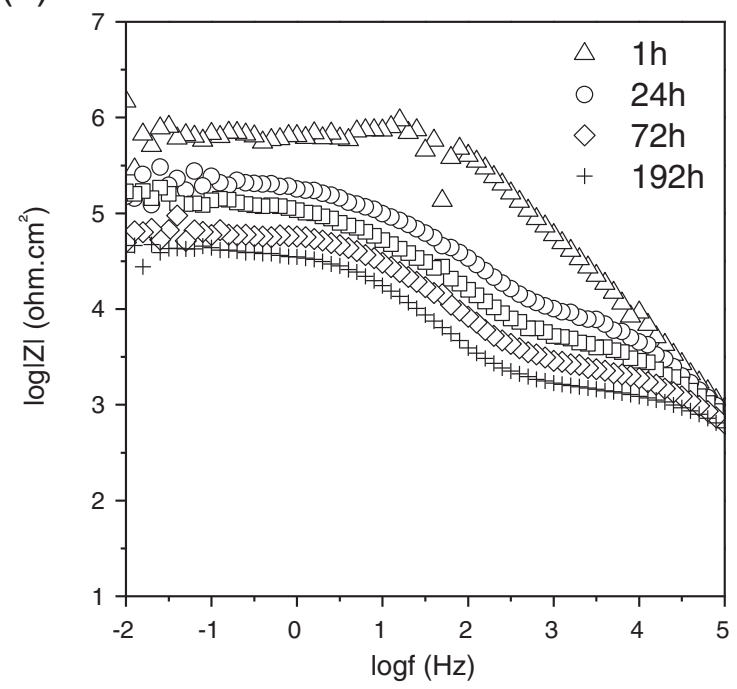

Fig. 14. Evolution of the EIS spectra of the El21 substrate coated with the duplex system conversion layer $\left(10 \mathrm{~g} \mathrm{~L}^{-1}\right)$ /sol-gel coating, during immersion in $0.05 \mathrm{M} \mathrm{NaCl}$.

based conversion layer, the surface of the El21 alloy is not regular, and tends to form discontinuities on the hybrid sol-gel coating, located at the spot of the neodymium and zirconium compounds. The cross-section SEM images show that the hybrid sol-gel coating has a lower thickness in these points, representing a weak point on the hybrid coating, offering inferior protection against corrosive species and representing a source of corrosion.

\section{Acknowledgments}

This work was carried out in the framework of the CARAIBE project. The FDA and the OSEO are gratefully acknowledged for the funding provided for this project. The authors would like to thank the partners of the project: Liebherr, Turbomeca, Eurocopter, Mecaprotec, Fondérie Messier and the Institut Carnot CIRIMAT.

\section{References}

[1] M. Pourbaix, Atlas D'équilibres Électrochimiques, 1963, pp. 140-145.

[2] T. Takenaka, T. Ono, Y. Narazaki, Y. Naka, M. Kawakami, Electrochim. Acta 53 (2007) 117.

[3] Y.L. Cheng, T.W. Qin, H.M. Hui, H.M. Wang, Z. Zhang, Trans. Nonferrous Met. Soc China 19 (2009) 517. 
(a)
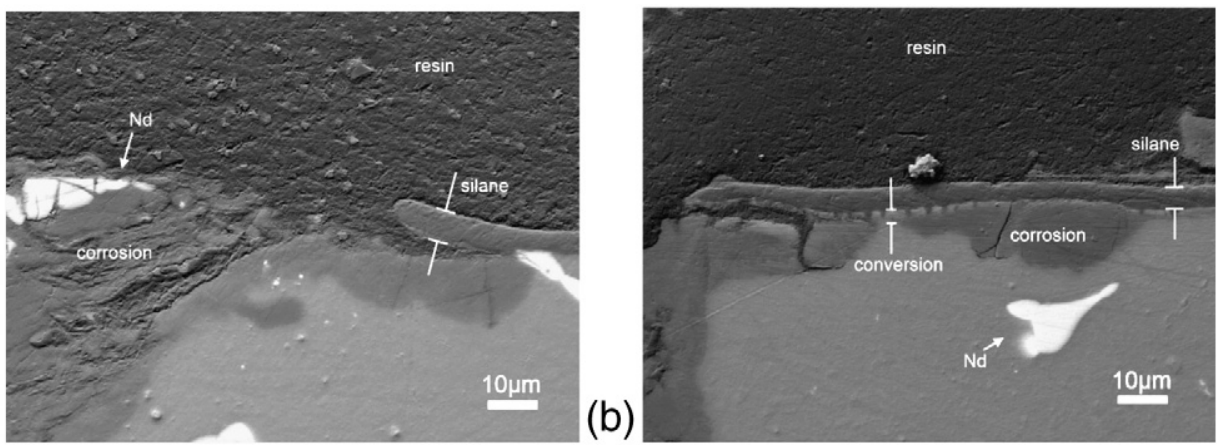

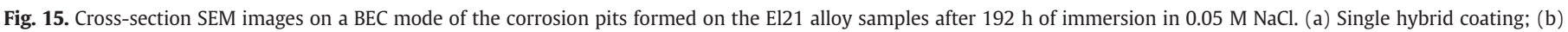
duplex system $\left(10 \mathrm{~g} \mathrm{~L}^{-1} \mathrm{H}_{3} \mathrm{PO}_{4}\right)$.

[4] Q. Wang, Y. Liu, S. Fang, Y. Song, D. Zhang, L. Zhang, C. Li, Mater. Charact. 61 (2010) 674

[5] M.B. Kannan, W. Dietzel, C. Blawert, A. Atrens, P. Lyon, Mater. Sci. Eng., A 480 (2008) 529.

[6] J.E. Gray, B. Luan, J. Alloys Compd. 336 (2002) 88.

[7] R.G. Hu, S. Zhang, J.F. Bu, C.J. Lin, G.L. Song, Prog. Org. Coat. 73 (2012) 129.

[8] U.C. Nwaogu, C. Blawert, N. Scharnagl, W. Dietzel, K.U. Kainer, Corros. Sci. 51 (2009) 2544.

[9] Y. Zhu, G. Yu, B. Hu, X. Lei, H. Yi, J. Zhang, Appl. Surf. Sci. 256 (2010) 2988.

[10] W. Zhou, D. Shan, E.H. Han, W. Ke, Corros. Sci. 50 (2008) 329.

[11] Y. Cheng, H. Wu, Z. Chen, H. Wang, L. Li, Trans. Nonferrous Met. Soc. China 16 (2006) 1086.

[12] M. Zhao, S. Wu, P. An, J. Luo, Mater. Chem. Phys. 103 (2007) 475

[13] F. Pan, X. Yang, D. Zhang, Appl. Surf. Sci. 255 (2009) 8363.

[14] M. Mosialek, G. Mordarski, P. Nowak, W. Simka, G. Nawrat, M. Hanke, R.P. Socha, J. Michalska, Surf. Coat. Technol. 206 (2011) 51.

[15] M. Zhao, S. Wu, J. Luo, Y. Fukuda, H. Nakae, Surf. Coat. Technol. 200 (2006) 5407.

[16] X. Wang, G. Yu, Y. Ouyang, X. He, J. Zhang, L. Ye, Trans. Nonferrous Met. Soc. China 19 (2009) 504.

[17] T.F. da Conceicao, N. Scharnagl, W. Dietzel, C. Blawert, K.U. Kainer, Thin Solid Films 518 (2010) 5209.

18] X. Liu, Z. Liu, P. Liu, Y. Xiang, W. Hu, W. Ding, Trans. Nonferrous Met. Soc. China 20 (2010) 2185.

[19] T.F. da Conceicao, N. Scharnagl, W. Dietzel, D. Hoeche, K.U. Kainer, Corros. Sci. 53 (2011) 712

[20] M. Turhan, R. Lynch, M. Killian, S. Virtanen, Electrochim. Acta 55 (2009) 250

[21] H. Elsentriecy, K. Azumi, H. Konno, Surf. Coat. Technol. 202 (2007) 532.

[22] A. Zomorodian, F. Brusciotti, A. Fernandes, M.J. Carmezim, T. Moura e Silva, J.C.S. Fernandes, M.F. Montemor, Surf. Coat. Technol. 206 (2012) 4368.

[23] F. Brusciotti, D.V. Snihirova, H. Xue, M.F. Montemor, S.V. Lamaka, M.G.S. Ferreira Corros. Sci. 67 (2013) 82.

24] A.L. Rudd, C.B. Breslin, F. Mansfeld, Corros. Sci. 42 (2000) 275.

[25] K. Brunelli, M. Dabala, I. Calliari, M. Magrini, Corros. Sci. 47 (2005) 989.

[26] M.F. Montemor, A.M. Simões, M.G.S. Ferreira, M.J. Carmezim, Appl. Surf. Sci. 254 (2008) 1806.

[27] D. Hawke, D.L. Albright, Met. Finish. 93 (1995) 34

[28] J. Liu, J.C. Berg, J. Mater. Chem. 17 (2007) 4430.

[29] T.L. Metroke, O. Kachurina, E.T. Knobbe, Prog. Org. Coat. 44 (2002) 295.

[30] M.L. Zheludkevich, R. Serra, G. Grundmeier, L.H. Yang, M.G.S. Ferreira, Surf. Coat Technol. 200 (2006) 4040.
[31] R. Zandi-zand, A. Ershad-langroudi, A. Rahimi, Prog. Org. Coat. 53 (2005) 286

[32] K.A. Yasakau, M.L. Zheludkevich, O.V. Karavai, M.G.S. Ferreira, Prog. Org. Coat. 63 (2008) 352.

[33] J.B. Cambon, F. Ansart, J.P. Bonino, V. Turq, Prog. Org. Coat. 75 (2012) 486.

[34] D. Wang, G.P. Bierwagen, Prog. Org. Coat. 64 (2009) 327.

[35] M.F. Montemor, M.G.S. Ferreira, Electrochim. Acta 52 (2007) 7486

[36] S.V. Lamaka, G. Knörnschild, D.V. Snihirova, M.G. Taryba, M.L. Zheludkevich, M.G.S. Ferreira, Electrochim. Acta 55 (2009) 131.

[37] P.S. Correa, C.F. Malfatti, D.S. Azambuja, Prog. Org. Coat. 72 (2011) 739

[38] V. Barranco, N. Carmona, J.C. Galvan, M. Grobelny, L. Kwiatkowsky, M.A. Villegas, Prog. Org. Coat. 68 (2010) 347

[39] A.F. Galio, S.V. Lamaka, M.L. Zheludkevich, L.F. Dick, I.L. Müller, M.G.S. Ferreira, Surf. Coat. Technol. 204 (2010) 1479

[40] F. Zucchi, V. Grassi, A. Frignani, C. Monticelli, G. Trabanelli, Surf. Coat. Technol. 200 (2006) 4136.

[41] F. Zucchi, A. Frignani, V. Grassi, A. Balbo, G. Trabanelli, Mater. Chem. Phys. 110 (2008) 263.

[42] V. Meiffren, K. Dumont, P. Lenormand, F. Ansart, S. Manov, Prog. Org. Coat. 71 (2011) 329.

[43] J.W. Chang, P.H. Fu, X.W. Guo, L.M. Peng, W.J. Ding, Corros. Sci. 49 (2007) 2612.

[44] G. Baril, N. Pebere, Corros. Sci. 43 (2001) 471.

[45] G. Galicia, N. Pebere, B. Tribollet, V. Vivier, Corros. Sci. 51 (2009) 1789.

[46] S.V. Lamaka, M.F. Montemor, A.F. Galio, M.L. Zheludkevich, C. Trinidade, L.F. Dick, M.G.S. Ferreira, Electrochim. Acta 53 (2008) 4773.

[47] P.C. Banerjee, R.K.S. Raman, Electrochim. Acta 56 (2011) 3790.

[48] L. Yang, Y. Wei, L. Hou, D. Zhang, Corros. Sci. 52 (2010) 345.

[49] R. Arrabal, A. Pardo, M.C. Merino, M. Mohedano, P. Casajús, K. Paucar, G. Garcés, Corros. Sci. 55 (2012) 301.

[50] R. Arrabal, E. Matykina, A. Pardo, M.C. Merino, K. Paucar, M. Mohedano, P. Casajús, Corros. Sci. 55 (2012) 351

[51] T. Zhang, G. Meng, Y. Shao, Z. Cui, F. Wang, Corros. Sci. (2011) 2934.

[52] G. Pettersen, H. Westengen, R. Hoier, O. Lohne, Mater. Sci. Eng., A 207 (1996) 115.

[53] A.L.K. Tan, A.M. Soutar, I.F. Annergren, Y.N. Liu, Surf. Coat. Technol. 198 (2005) 478.

[54] A.N. Khramov, V.N. Balbyshev, L.S. Kasten, R.A. Mantz, Thin Solid Films 514 (2006) 174.

[55] F. Zucchi, A. Frignani, V. Grassi, G. Trabanelli, M. DalColle, Corros. Sci. 49 (2007) 1570 . 